\title{
Improvement of Torsional Resistance in Ultra-High Performance Fibre Reinforced Concrete Beams
}

\section{Karim FR ${ }^{1 *}$, Abu Bakar BH $^{2}$ and Choong Kok Keong ${ }^{3}$}

${ }^{1} P h D$ candidate, Universiti Sains Malaysia, School of Civil Engineering

${ }^{2}$ Prof. Dr. in School of Civil Engineering, Universiti Sains Malaysia

${ }^{3}$ Associated Prof.Dr in School of Civil Engineering, Universiti Sains Malaysia

\begin{abstract}
This research highlights the effect of concrete cover on the behavior of ultra-high performance fiber reinforced concrete rectangular solid beams under pure torsion. The main parameter in this research is the thickness of concrete cover which is varying between 21 and $52 \mathrm{~mm}$. For this purpose, four under-reinforced ultra-high performance fibre reinforced concrete rectangular solid beams were cast and they were tested under pure equilibrium torsion. The test results verified that the torsional resistance at peak and crack loads were improved up to $113 \%$ and $134 \%$, respectively, of the estimated value based on thin walled tube theory. Moreover, all of the twisting angle at ultimate load and shear strain in concrete were found to decrease up to $64.9 \%, 40.1 \%$, respectively. In addition, both strain in longitudinal reinforcement and strain in stirrup were reduced up to $50 \%$. The space truss analogy was modified to be compatible with this parameter effect. The modified model showed that it has a good agreement with test results.
\end{abstract}

Keywords: UHPFRC; Concrete cover; Thin-walled tube analogy; Ultra-high performance; Torsional Resistance; Fibre reinforced; Concrete beams

\section{Introduction}

Ultra-high performance fibre reinforced concrete (UHPFRC) is an especial kind of concrete which has high compressive and relatively high tensile strength. However, this concrete has a high value of brittleness index in comparison with fibrous normal and high strength concrete. Therefore, cracking in this type of concrete could be occured and propagated suddenly.

The torsional resistance in UHPFRC beams is provided by concrete prior to cracking and reinforcements plus fibres at post cracking stages because the concrete carries tensile stress in the pre-crack stage and reinforcements with fibres carry tensile stress in the post cracking stage.

The contribution of the concrete, fibre and reinforcements is influenced by using of UHPFRC. The torsional resistance provided by fibres is improved due to high volume fraction ratio in the concrete. Furthermore, the amount of stress in the reinforcement in post cracking stage is reduced due to thick concrete cover. The thickness of concrete cover is more, the stress in reinforcements are less. Therefore, the contribution of reinforcements to resist torsion after cracking reduced [1].

The most important point in torsional resistance in non-fibrous concrete beams is the thickness of concrete cover. The thickness of concrete cover is the inflection point for the torsional resistance. When concrete beams have a small thickness, the torsional resistance of the beams tends to be over-strengthened and vice versa [2].

Despite the fact that the probability of producing concrete spalls off due to thick concrete cover was small in fibrous concrete [3], the concrete cover was contributed to resist torsion in pre-crack and postcrack stages. In contrast, the concrete cover in non-fibrous concrete tend to spall off while it was thick and the outermost dimensions of the concrete cross section of beams reduced to the dimensions of the centerline of stirrups [4].

\section{Research significance}

This paper highlights the effect of thickness of concrete cover on the torsional resistance of ultra-high performance fibre reinforced concrete beams at pre-crack and post-crack stages. Even though the previous researches have conducted in studies on non-fibrous concrete beams to determine the influence of the concrete cover and they found that thickening of concrete cover is useless and the torsional resistance of the concrete beams tends to be under-estimated strength, regardless the eliminate of concrete spalls off which comes by inclusion fibres.

\section{Experimental programme}

The under-reinforced concrete (B-1-UH) beam is the control beam and the other beams (C-1-UH, C-2-UH and C-3-UH) with varying thickness of concrete cover were cast for experimental purpose. The concrete cover of the beams was varied from 21 to $52 \mathrm{~mm}$. The span to depth ratio and the aspect ratio of the beam section are kept as 5.70 and 1.20, respectively. The torsional moment was applied on the beams from two point loads acting on the loading arms which are altered to pure torsion on the tested beam.

\section{Materials, Mix Proportions and Specimen Preparation \\ Materials}

The ultra-high performance fibre reinforced concrete beams were cast with cube compressive strength $127 \mathrm{MPa}$. An ordinary Portland cement (Tasik cement) was used. Quartz sand with $0.6 \mathrm{~mm}$ and 0.325 $\mathrm{mm}$ as an average sieve size, glass powder, silica fume, tap water, HRWR super-plasticizer Sika VC2055, retard-admixture Plastiment-R with two size of micro steel fibre were used. The mix proportion of the materials used for producing UHPFRC is shown in Table 1.

*Corresponding author: Ferhad Rahim Karim, School of Civil Engineering Universiti Sains Malaysia, 14300 Nibong Tebal, Seberang Perai, Pinang, Malaysia, Tel. 0060-(0)111-451-39-13; E-mail: f1974e1997m2004@gmail.com

Received April 10, 2016; Accepted May 26, 2016; Published June 06, 2016

Citation: Karim FR, Abu Bakar BH, Choong Kok Keong (2016) Improvement of Torsional Resistance in Ultra-High Performance Fibre Reinforced Concrete Beams. J Steel Struct Constr 2: 112. doi:10.4172/2472-0437.1000112

Copyright: ( 2016 Karim FR, et al. This is an open-access article distributed under the terms of the Creative Commons Attribution License, which permits unrestricted use, distribution, and reproduction in any medium, provided the original author and source are credited. 
Citation: Karim FR, Abu Bakar BH, Choong Kok Keong (2016) Improvement of Torsional Resistance in Ultra-High Performance Fibre Reinforced Concrete Beams. J Steel Struct Constr 2: 112. doi:10.4172/2472-0437.1000112

Page 2 of 8

\section{Proportioning of beam specimen}

The longitudinal reinforcement consisted of 6-12 $\mathrm{mm}$ diameter bars, three of them at the bottom and the rest at the top. The transverse reinforcement was provided in the form of two-leg rectangular stirrups with $135^{\circ}$ standard hooks. The $6 \mathrm{~mm}$ diameter bars were made stirrups with dimension $166 \mathrm{~mm}$ wide and $216 \mathrm{~mm}$ depth and the spacing between stirrups was $95 \mathrm{~mm}$ as shown in Figure 1 [5]. The dimensions of the beams are tabulated in Table 2 .

\section{Specimen preparation}

The UHPFRC was blended in the two pan mixer with $0.05 \mathrm{~m}^{3}$ capacity using the following procedure: Quartz sands and silica fume were blended for 5 minutes. Then, the cement and glass powder were mixed with them for another 5 minutes.

Next, the entire amount of water and super-plasticizer were added to the mix for another 4 minutes. Afterwards, the retarder-admixture (Plastiment R) was added to the mix for another 4 minutes. After that, micro steel fibre was added to the blending materials by passing the fibre through the steel wire mesh during 1 minute. The blending process was continued for an additional two minutes to enhance the uniform distribution of fibre in the concrete [6].

UHPFRC was cast in the mold with three $100 \mathrm{~mm}$ side length cube [7], three cylinder $100 \mathrm{~mm}$ diameter [8], three prisms $100 \times 100 \times 500$ $\mathrm{mm}$ [9] and six bond cubes $100 \mathrm{~mm}$ side length [10] were cast together with 10 seconds vibration.

\section{Testing of beams}

UHPFRC beams were tested for pure torsion under Universal Testing Machine of $500 \mathrm{kN}$ capacity in the Structural Laboratory in the School of Civil Engineering. The specimens are tested in pure torsion test arrangement as shown in Figures 2 and 3. The twisting angles were measured from LVDT on the $\mathrm{U}$ steel frame shown in the Figure 4. The strain in concrete and reinforcements were measured by LVDT and electrical strain gauges. The load was applied until the beam failed under pure torsion.

\section{Results and Discussion}

The torsional resistance and twisting angles at crack and peak loads were calculated. In addition, the inclination angle of crack at failure was measured as shown in Table 3.

\section{Cracking torsional moment}

The cracking torsional resistance is improved up to $133.9 \%$ due to thickening of concrete cover. In contrast, it is slightly effected by the compressive strength of concrete as shown in Figure 5.

\section{Torsional resistance provided by reinforcement and fibre}

The torsional resistance provided by fibre and reinforcement is improved up to $94.66 \%$ due to extra thickness of concrete cover which behaves like a hollow section under tension. Thus, the torsional resistance provided by fibre is improved as shown in Figure 6.

\section{Torsional moment and twisting angle}

The twisting angle is reduced up to $88.6 \%$ and $71.21 \%$ at crack and peak loads due to enhancement of the section stiffness from thickening of concrete cover as shown in Figure 7 and Table 4.

\section{Shear strain in concrete}

The value of shear strain is improved up to $105 \%$ due to thickening of concrete cover at crack load whereas it is reduced up to $71 \%$ at peak load because of the extra concrete cover which produced tension in extra thickness instead of compression as shown in Figure 8. The stress in the extreme fibre of concrete is changed from compression to tension. Thus, the space truss analogy is not compatible to apply to the section with thickening of concrete cover.

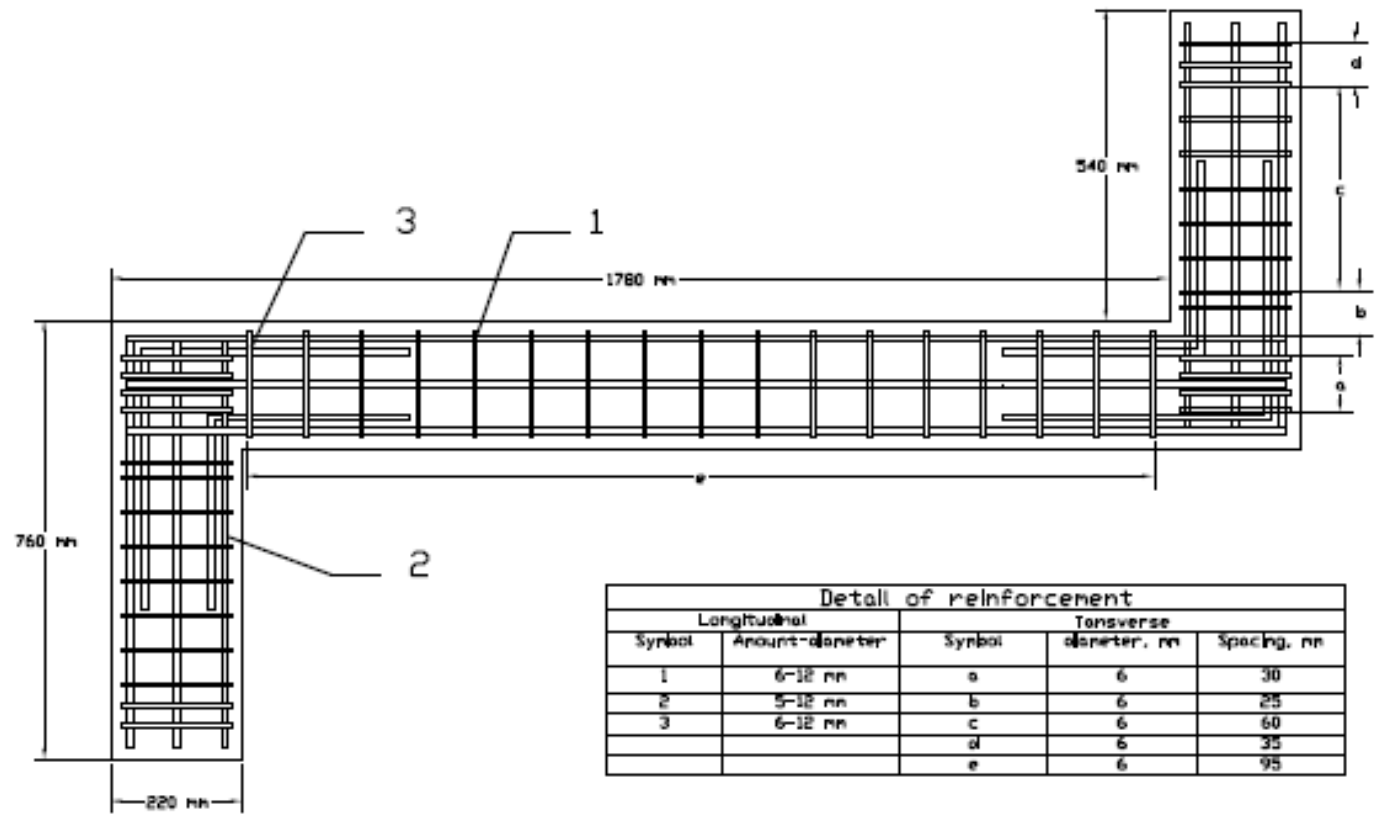

Figure 1: Detail of reinforcements in the beams. 
Citation: Karim FR, Abu Bakar BH, Choong Kok Keong (2016) Improvement of Torsional Resistance in Ultra-High Performance Fibre Reinforced Concrete Beams. J Steel Struct Constr 2: 112. doi:10.4172/2472-0437.1000112

Page 3 of 8

\section{Strain in longitudinal and transverse reinforcements}

The value of strain in both reinforcements is shown in Figures 9 and 10. The strains of longitudinal and transverse reinforcements are reduced up to $57.3 \%$ and $68.3 \%$ due to change in the position of centre of shear flow zone. Therefore, the contribution of reinforcement is reduced to resist torsion. Indeed, this reduction of the strain does not come from tension stiffening.

\section{Detail and crack patterns}

The pattern of cracks of tested beams under pure torsion is affected by the thickness of concrete cover as shown in Figures 11-14. It was observed that the number of spiral cracks is increased due to decreasing thickness of concrete cover. Consequently, the average spacing between spiral cracks and inclination angle of crack at failure are decreased as shown in Table 5.

\section{Theoretical Model}

The fibrous concrete section with extra thickness in concrete cover is behaved as the two parts to resist torsional moment. The first part is idealized solid section and the second part is idealized hollow section as shown in Figure 15. The latter improves torsional resistance provided by concrete and fibre.

The concrete section of the beam with extra thickness of concrete cover might be behaved as a hollow section with the thickness of extra concrete cover surrounded the idealized solid section. The stress in the concrete surface tends to be in tension. Even though the stress in the reinforcements are reduced due to the surrounded ultra-high performance fibre reinforced concrete cover thickness, thin-walled

\begin{tabular}{|c|c|}
\hline Materials & Quantity, $\mathbf{~ k g} / \mathbf{m}^{\mathbf{3}}$ \\
\hline Cement ( Type I) & 1500 \\
\hline Quartz sand 0.6 mm & 539.5 \\
\hline Quartz sand 0.325 mm & 110.5 \\
\hline Silica fume & 175 \\
\hline Glass powder & 126.08 \\
\hline water & 372.76 \\
\hline Water reducing super-plasticizer VC2055 & 38.23 \\
\hline Retard-admixture (Plastiment-R) & 7.49 \\
\hline Micro steel fibre A(21 mm $\times 0.35 \mathrm{~mm} \Phi)$ & 26.50 \\
\hline Micro steel fibre B(12 $\mathrm{mm} \times 0.20 \mathrm{~mm} \Phi)$ & 150.13 \\
\hline Slump-flow, $\mathrm{mm}[6]$ & 720 \\
\hline
\end{tabular}

Table 1: Mix proportion of UHPFRC

\begin{tabular}{|c|c|c|c|c|}
\hline $\begin{array}{c}\text { Beam } \\
\text { designation }\end{array}$ & $\begin{array}{c}\text { Concrete } \\
\text { cover, } \mathbf{m m}\end{array}$ & Width, mm & Height, mm & Span length, mm \\
\hline B-1-UH & 21 & 214 & 264 & 1533 \\
\hline C-1-UH & 21 & 214 & 264 & 1484 \\
\hline C-2-UH & 31 & 234 & 284 & 1630 \\
\hline C-3-UH & 52 & 276 & 326 & 1887 \\
\hline \multicolumn{4}{|c}{ Table 2: Details of the beams. } \\
\hline
\end{tabular}

tube analogy theory is applied on the idealized solid section with using actual stress in the reinforcement. Thus, the idealized tube or hollow section contributes to resist the torsional moment provided by concrete and fibres.

Therefore, the torsional resistance of the whole section is the sum of the torsional resistance by idealized solid section and hollow section. The contribution of concrete, reinforcement and fibres in idealized solid and hollow sections are modified the space truss model as follows:

1. Contribution of transverse steel reinforcements in idealized solid section $\mathrm{T}_{\mathrm{s}}$ could be expressed as follows after modification. The stress of transverse reinforcement is changed with respect to the thickness of concrete cover.

$T_{s}=\frac{2 \cdot A_{o} \cdot A_{t}}{S}\left(-0.0009 C^{2}+0.0417 C+0.5391\right) \cdot f_{y} \cdot \cot \theta$

2. Contribution of fibre of idealized hollow section $\mathrm{T}_{\mathrm{fh}}$ only to resist torsional moment because this area in the section is under tension.

$T_{f h}=\frac{X_{1}^{2}}{2}\left(Y_{1}-\frac{X_{1}}{3}\right) \cdot\left(\frac{f_{s p} \cdot f_{c^{\prime}}}{f_{s p}+f_{c^{\prime}}}\right)$

3. Contribution of concrete of idealized solid and hollow section $\mathrm{T}_{\text {cr }}$ and $\mathrm{T}_{\text {crh }}$ to resist torsional moment prior to cracking, respectively.

$$
\begin{aligned}
& T_{c r}=\frac{1}{4}\left(\frac{-0.273+4.14 f_{c^{\prime}}^{-0.677}}{0.098+f_{c^{\prime}}^{-0.677}}\right) \sqrt{f_{c^{\prime}}} \frac{A_{c p}^{2}}{P_{c p}} \\
& T_{c r h}=0.16607 \sqrt{f_{c^{\prime}} \cdot\left(\frac{B . H^{3}-X . Y^{3}}{6 . H}\right)} \\
& T_{u}=T_{s} \mp T_{f h}+T_{c r} \mp T_{c r h}
\end{aligned}
$$

Where;

$\mp:$ it is positive if the section has extra thickness from the effective thickness for resisting torsion provided by ACI building code and vice versa.

\section{Evaluation of the Proposed Model}

Evaluation of the proposed model was formulated to predict the torsional resistance in ultra-high performance fibre reinforced concrete beams as tabulated in Table 6 . It was found that the proposed equation slightly over-estimated the value of torsional resistance of underreinforced UHPFRC beams at peak load because of the mean of the measured torsional resistance to predict one is 0.971 (Table 6).

\section{Conclusions}

Based on the results from pure torsion test of ultra-high performance fibre reinforced concrete, the following conclusions could be made:

\begin{tabular}{|c|c|c|c|c|}
\hline \multirow{2}{*}{ Beam designation } & $\begin{array}{c}\text { Cube compressive } \\
\text { strength, MPa }\end{array}$ & $\begin{array}{c}\text { Split tensile strength, } \\
\text { MPa }\end{array}$ & $\begin{array}{c}\text { Flexural strength, } \\
\text { MPa }\end{array}$ & \multicolumn{2}{|c|}{$\begin{array}{c}\text { Bond strength, MPa } \\
\text { Treansverse reinforcement }\end{array}$} & \begin{tabular}{c} 
Longitudinal reinforcement \\
\hline B-1-UH
\end{tabular} & 127.502 & 10.335 & 12.841 & 7.362 \\
\hline C-1-UH & 135.770 & 15.285 & 12.065 & 7.588 \\
\hline C-2-UH & 135.430 & 15.945 & 9.572 & 6.791 \\
\hline C-3-UH & 132.090 & 14.252 & 10.378 & 7.152 \\
\hline
\end{tabular}

Table 3: Properties and details of the beams. 
Citation: Karim FR, Abu Bakar BH, Choong Kok Keong (2016) Improvement of Torsional Resistance in Ultra-High Performance Fibre Reinforced Concrete Beams. J Steel Struct Constr 2: 112. doi:10.4172/2472-0437.1000112

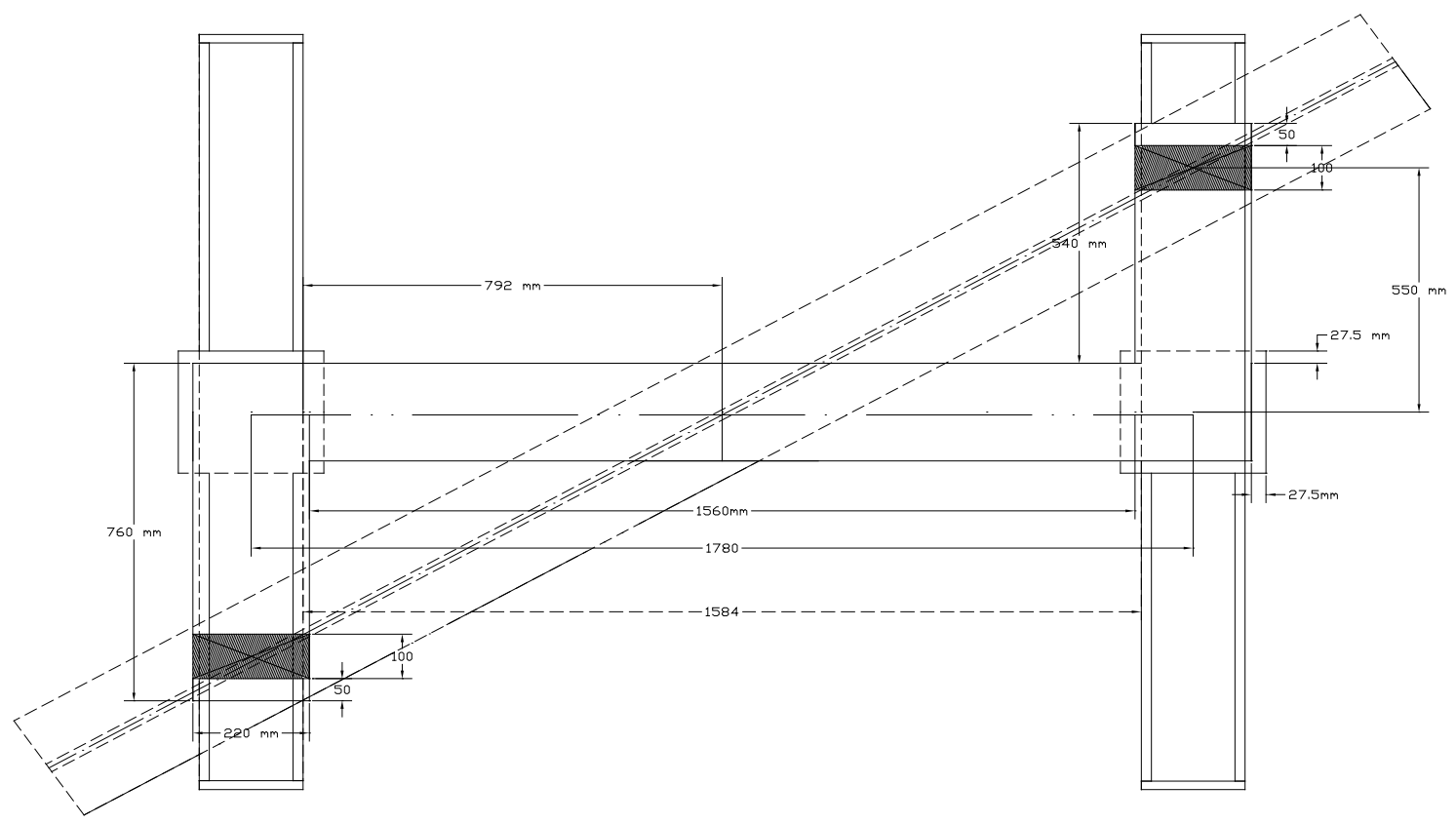

Figure 2: Schematic test setup.

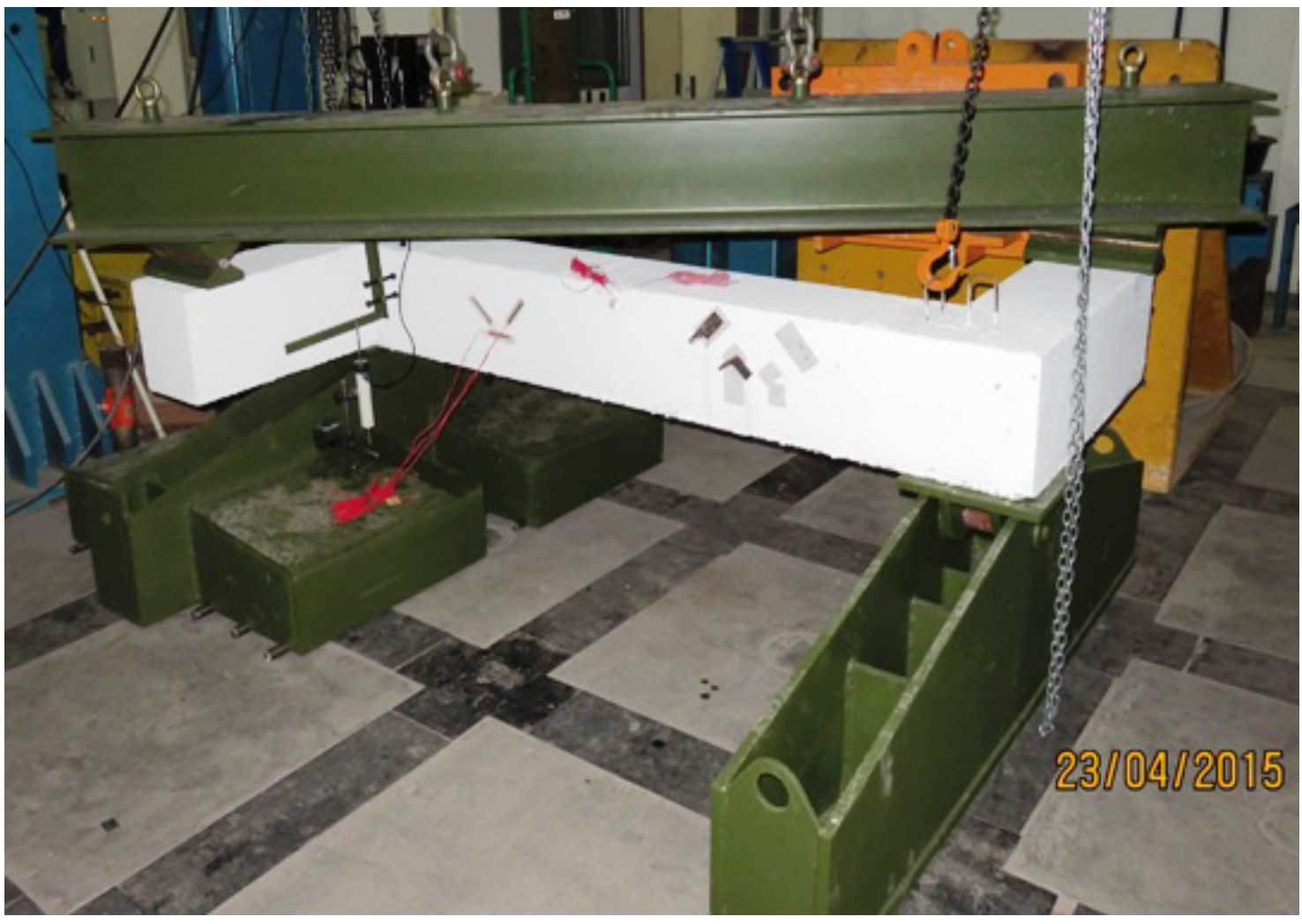

Figure 3: Experimental setup of the beam. 


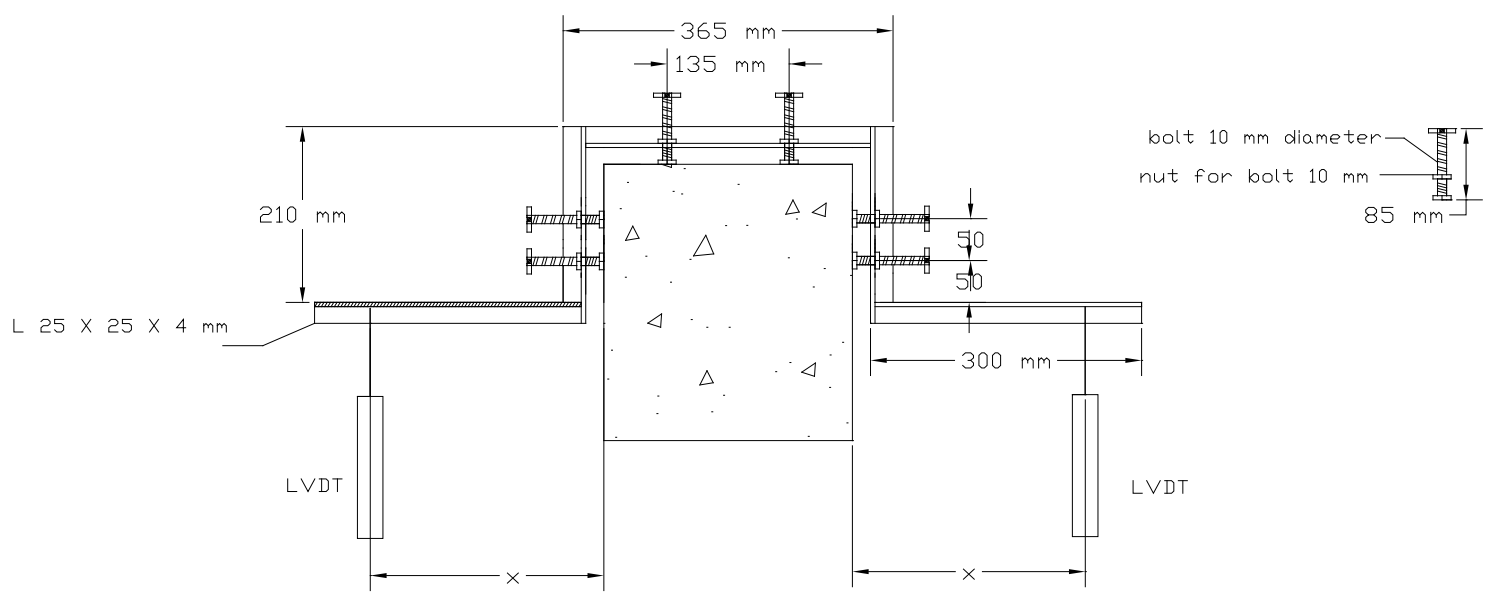

Figure 4: Schematic measuring of twisting angle.

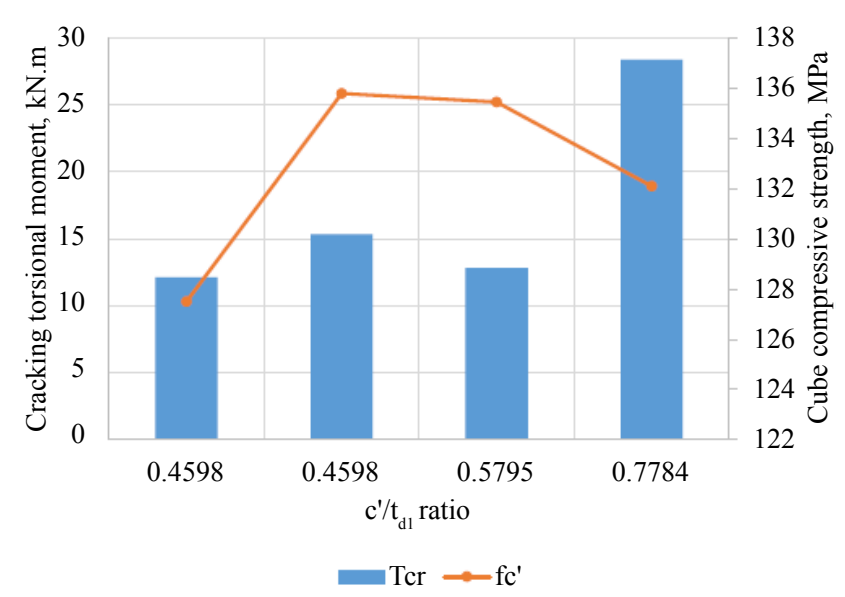

Figure 5: Effect of concrete cover on the cracking torsional resistance.

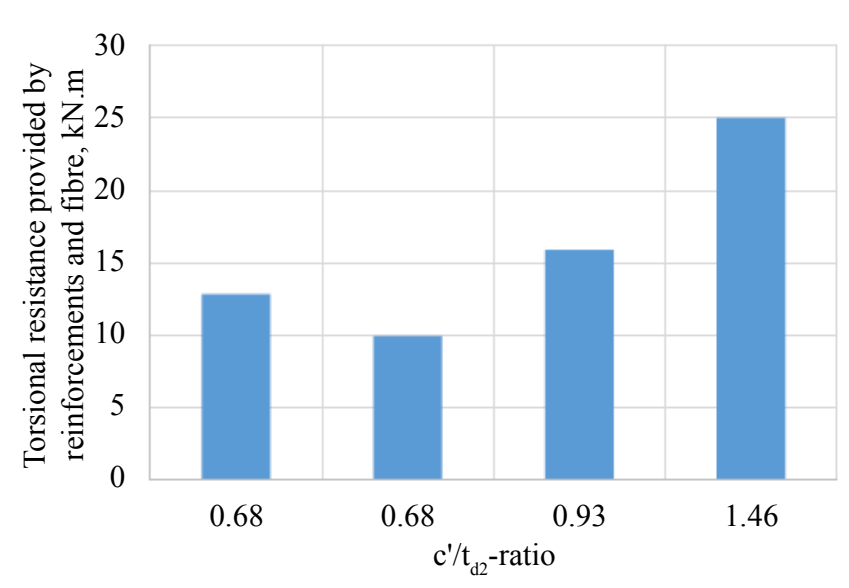

Figure 6: Effect of concrete cover on the cracking torsional resistance.

1. Due to increase in the thickness of concrete cover, the torsional resistance provided by concrete and reinforcement plus fibre are improved up to $134 \%$ and $94.66 \%$, respectively.

2. The twisting angle, shear strain in concrete, and the strain in

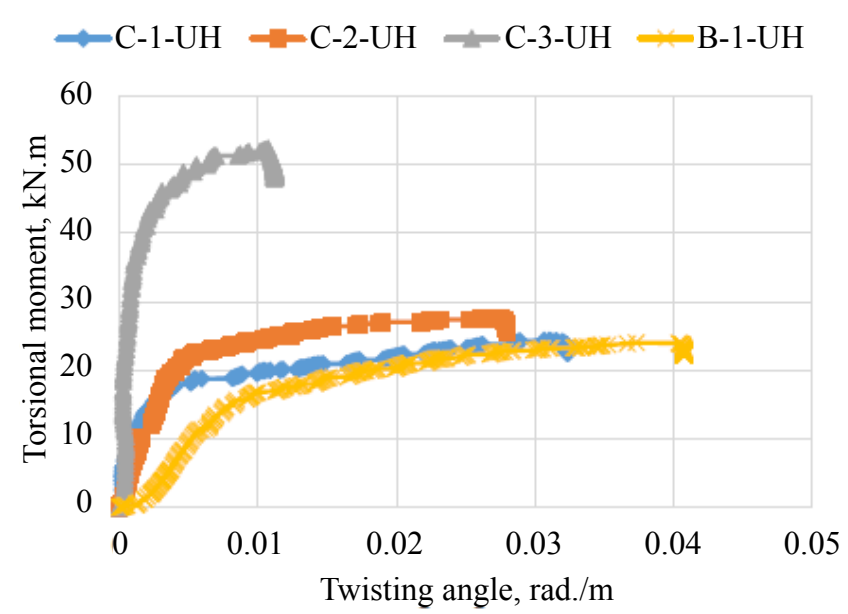

Figure 7: Torsional resistance versus twisting angle.

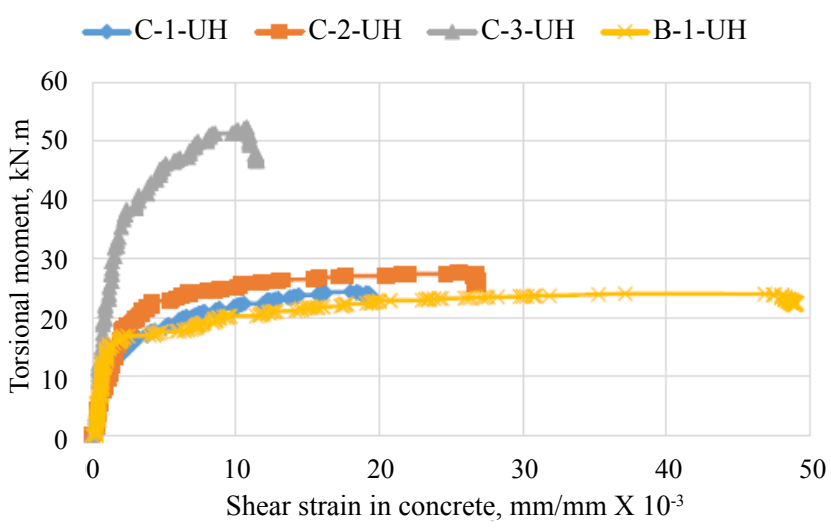

Figure 8: Torsional resistance versus shear strain in concrete.

longitudinal and transverse reinforcements are reduced at peak load up to $71.21 \%, 71 \%, 57.3 \%$ and $68.3 \%$ due to extra thickness of concrete cover, respectively.

3. The spacing between spiral cracks is increased owing to extra 
Citation: Karim FR, Abu Bakar BH, Choong Kok Keong (2016) Improvement of Torsional Resistance in Ultra-High Performance Fibre Reinforced Concrete Beams. J Steel Struct Constr 2: 112. doi:10.4172/2472-0437.1000112

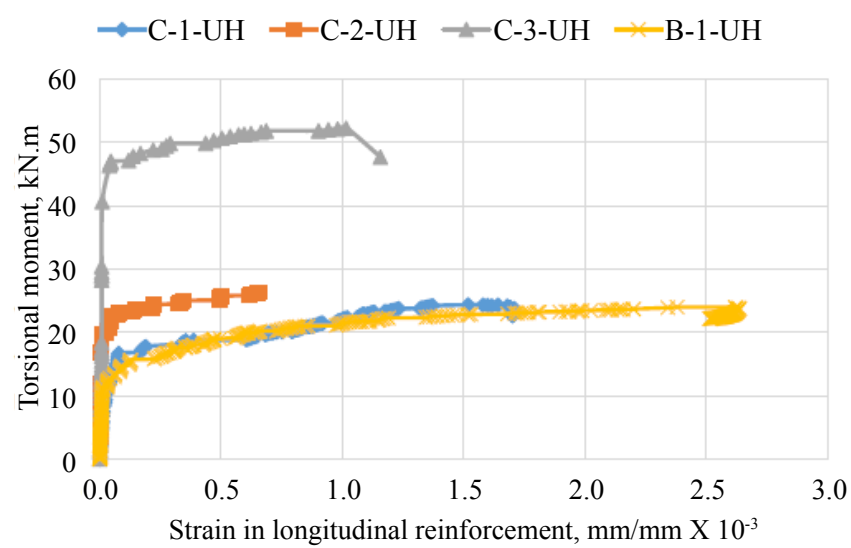

Figure 9: Torsional resistance versus strain in longitudinal reinforcement.

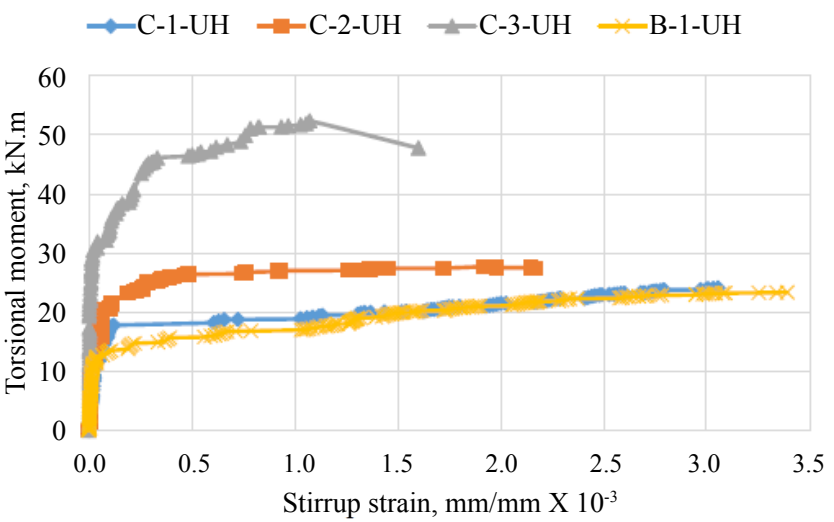

Figure 10: Torsional resistance versus strain in transverse reinforcement.

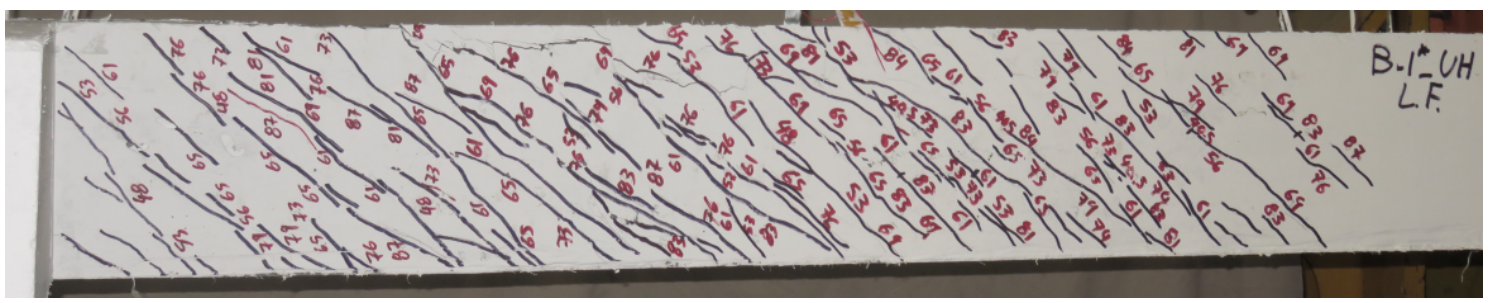

Figure 11: Crack patterns of beam B-1-UH.

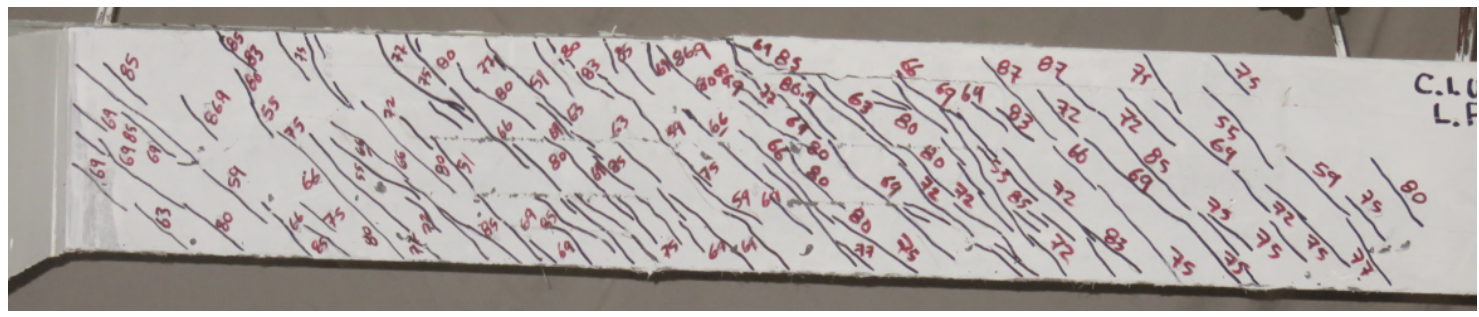

Figure 12: Crack patterns of beam C-1-UH.

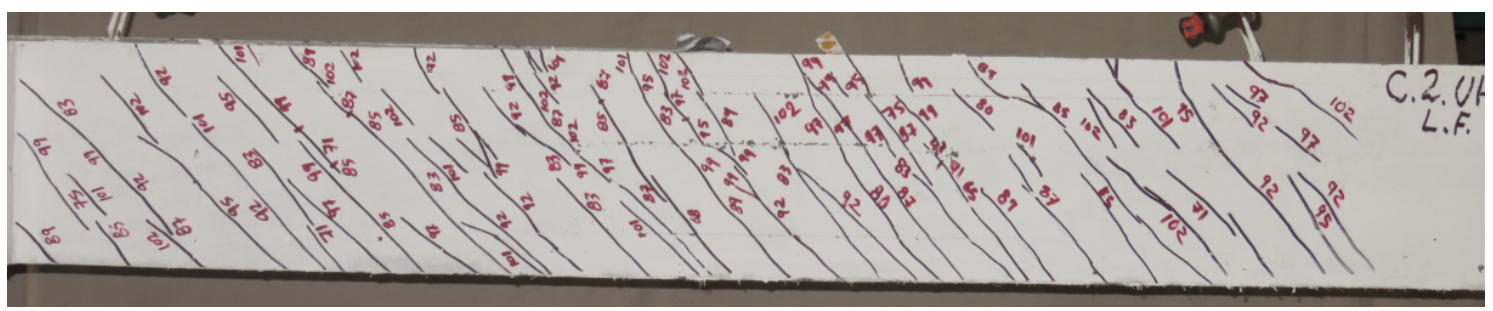

Figure 13: Crack patterns of beam C-2-UH.

\begin{tabular}{|c|c|c|c|c|c|}
\hline Beam & $\begin{array}{c}\text { Torsional } \\
\text { resistance at } \\
\text { crack load, kN.m }\end{array}$ & $\begin{array}{c}\text { Twisting angle at } \\
\text { crack load, rad/m } \\
\mathbf{X ~ 1 0 ^ { - 3 }}\end{array}$ & $\begin{array}{c}\text { Torsional } \\
\text { resistance at peak } \\
\text { load, kN.m }\end{array}$ & $\begin{array}{c}\text { Twisting angle at peak } \\
\text { load, rad/m X 10-3 }\end{array}$ \\
\hline B-1-UH & 12.11 & 5.655 & 24.96 & 37.28 \\
\hline C-1-UH & 15.329 & 2.163 & 25.287 & 30.636 \\
\hline C-2-UH & 12.803 & 1.831 & 28.678 & 42 \\
\hline C-3-UH & 28.337 & 0.645 & 53.351 & 46 \\
\hline failure, degree & 50 \\
\hline
\end{tabular}

Table 4: Results of pure torsion test in UHPFRC beams. 


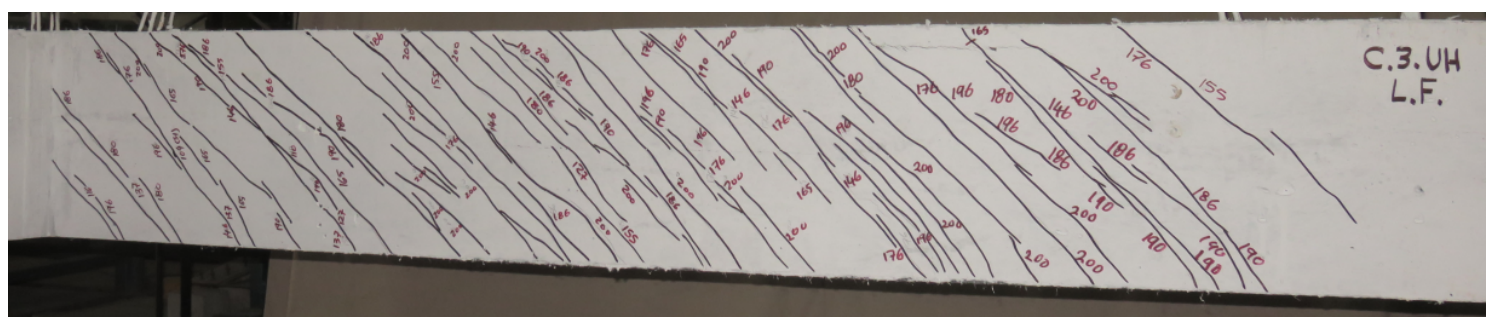

Figure 14: Crack patterns of beam C-3-UH.

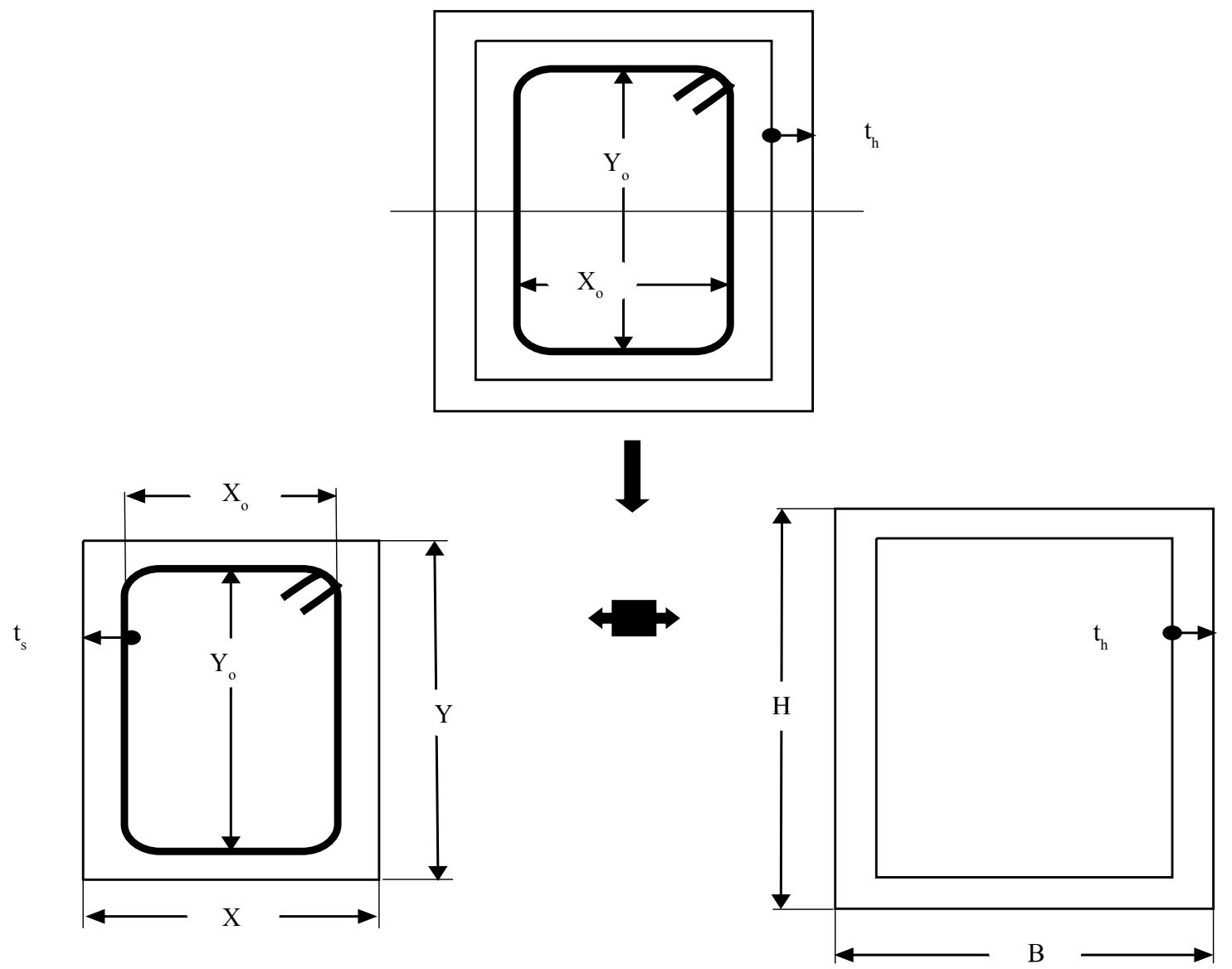

Figure 15: Idealized solid and hollow sections

\begin{tabular}{|c|c|c|c|}
\hline Beam & $\begin{array}{c}\text { No. of spiral } \\
\text { cracks }\end{array}$ & $\boldsymbol{\theta}$, degree & $\begin{array}{c}\text { Average spacing between } \\
\text { spiral cracks, } \mathbf{m m}\end{array}$ \\
\hline B-1-UH & 14 & 42 & 95 \\
\hline C-1-UH & 12 & 46 & 115 \\
\hline C-2-UH & 7 & 50 & 191 \\
\hline C-3-UH & 8 & 52 & 193 \\
\hline
\end{tabular}

Table 5: Detail of spiral cracks.

thickness of concrete cover. Thus, the number of spiral cracks is reduced.

4. The stress in the extreme fibre of concrete is changed from compression to tension. Thus, the space truss is not compatible be applied to the whole section.

5. The proposed equation to predict torsional resistance at peak loads which includes the effect of concrete cover has been verified to show a good agreement with test results of underreinforced ultra-high performance fibre reinforced concrete beams.

\section{Further Research}

It is recommended to make further study on the UHPFRC beams under pure torsion with thin concrete cover or without cover to confirm the effect of thin concrete cover on the torsional resistance.

\section{Acknowledgment}

This work was conducted as part of the doctoral studies of the first author. The $\mathrm{PhD}$ programme has been financially supported by Kurdistan Government RegionIraq and Universiti Sains Malaysia, School of Civil Engineering which are gratefully acknowledged. 
Citation: Karim FR, Abu Bakar BH, Choong Kok Keong (2016) Improvement of Torsional Resistance in Ultra-High Performance Fibre Reinforced Concrete Beams. J Steel Struct Constr 2: 112. doi:10.4172/2472-0437.1000112

Page 8 of 8

\begin{tabular}{|c|c|c|c|c|c|c|c|}
\hline Beam & $\mathrm{T}_{\mathrm{cr} 1}, \mathrm{kN} . \mathrm{m}$ & $\mathrm{T}_{\mathrm{s}}, \mathrm{kN} \cdot \mathrm{m}$ & $\mathrm{T}_{\mathrm{cr2}}, \mathrm{kN} . \mathrm{m}$ & $T_{f}, k N . m$ & $\begin{array}{c}\text { Eq.5, Tn, } \\
\text { Predicted kN.m }\end{array}$ & $\begin{array}{l}\text { Tn, Measured, } \\
\text { kN.m }\end{array}$ & $\begin{array}{l}\text { Tn, Measured/Tn, } \\
\text { Predicted }\end{array}$ \\
\hline B-1-UH & 12.157 & 10.447 & 0.847 & 1.637 & 25.088 & 24.96 & 0.994 \\
\hline C-1-UH & 12.545 & 8.855 & 0.874 & 2.291 & 24.565 & 25.287 & 1.029 \\
\hline C-2-UH & 12.529 & 7.893 & 2.233 & 9.613 & 32.268 & 28.678 & 0.888 \\
\hline C-3-UH & 12.374 & 3.914 & 5.533 & 33.034 & 54.855 & 53.351 & 0.972 \\
\hline
\end{tabular}

Table 6: Evaluation of the proposed equation [5].

\section{REFERENCES}

1. Lee JY, Kim SW (2010) Torsional Strength of RC Beams Considering Tension Stiffening Effect. Journal Structural Engineering 136: 1367-1378.

2. Hsu TTC, Mo YL (1985) Softening of Concrete in Torsional Members-Design Recommendations. ACI Journal 82: 443-452.

3. Namiq ZF (2012) Effect of Steel Fibre on the Strength and Behavior of NonCircular Solid and Hollow Cross Section Beams under Pure Torsion. University of Salahaddin, Erbil, Iraq.

4. Rahal KN, Collins MP (1996) Simple Model for Predicting Torsional Strength of Reinforced and Prestressed Concrete Sections. ACI Structural Journal 93: 658-666.

5. ACl Committee 318 (2015) Building Code Requirements for Structural Concrete
(ACl 318M-14) Commentary (ACl 318RM-14). Detroit: American Concrete Institute, United States.

6. ASTM (2010) Standard test method for slump flow of self-consolidating concrete. Annual book of ASTM standards 4.02: 859-864.

7. BS EN (2002) Part3: Compressive strength of test specimens. BIS 12390: 1-15.

8. ASTM (2006) Standard Test Method for Splitting Tensile Strength of Cylindrical Concrete Specimens. Annual book of ASTM standards 4.02: 299-303.

9. ASTM (2010) Standard Test Method for Flexural Performance of Fibre Reinforced Concrete (Using Beam with Three-point Loading. Annual book of ASTM standards 4.02: 846-854.

10. IS (1967) Methods of testing bond in reinforced concrete Part I: Pull-out Test. Bureau of Indian standard 2770: 1-10. 